\title{
OPEN The selective adsorption performance and mechanism of multiwall magnetic carbon nanotubes for heavy metals in wastewater
}

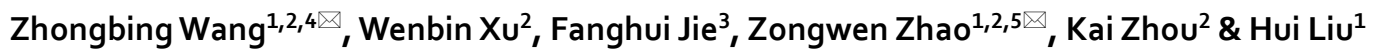

The safe treatment of heavy metals in wastewater is directly related to human health and social development. In this paper, a new type of recyclable adsorbent is synthesized through the oxidation of enhancer and modification with magnetic nanoparticles. The new adsorbent not only inherits the advantages of multiwall carbon nanotubes (6O-MWCNTs), but also exhibits a new magnetic property and further improved adsorption capacity, which is conducive to the magnetic separation and recovery of heavy metals. The adsorption results indicate that multiwall magnetic carbon nanotubes (60-MWCNTs@ $\mathrm{Fe}_{3} \mathrm{O}_{4}$ ) have a good performance for $\mathrm{Pb}$ (II) selective adsorption, with a maximum adsorption capacity of $215.05 \mathrm{mg} / \mathrm{g}$, much higher than the existing adsorption capacity of the same type of adsorbents. Under the action of an external magnetic field, 60-MWCNTs@ $\mathrm{Fe}_{3} \mathrm{O}_{4}$ that adsorbed metal ions can quickly achieve good separation from the solution. The joint characterization results of FTIR and XPS show that under the action of both coordination and electrostatic attraction, the $\mathrm{C}=\mathrm{O}$ bond in the $-\mathrm{COOH}$ group is induced to open by the metal ions and transforms into an ionic bond, and the metal ions are stably adsorbed on the surface of 6O-MWCNTs@ $\mathrm{Fe}_{3} \mathrm{O}_{4} \cdot \mathrm{Pb}$ (II) has a stronger attraction than $\mathrm{Cu}(\mathrm{II})$ and $\mathrm{Cd}(\mathrm{II})$ to the lone pair of electrons in oxygen atoms to form complexes, due to the covalent index of $\mathrm{Pb}$ (6.41) is more larger than that of $\mathrm{Cu}(2.98)$ and $\mathrm{Cd}(2.71)$. These data provide a new type of recyclable adsorbent for the efficient treatment of heavy metal ions in wastewater and enrich relevant theoretical knowledge.

With the rapid development of urbanization, industrialization, and agricultural activities, as an important medium for energy conversion and material migration, water resources are inevitably polluted by thousands of toxic and harmful substances produced in various ways. Pollutants in the water environment are roughly divided into two categories: inorganic pollutants and organic pollutants. Heavy metal pollution is a typical inorganic pollutant. Most heavy metals exist in a dissolved ion state and easily accumulate in the environment and organisms, which may cause serious hidden, lagging, and persistent compound pollution in the atmosphere, water, and soil environment ${ }^{1-3}$. Therefore, heavy metal pollution has become a major threat to human health and social development. How to more efficiently treat heavy metal ions in wastewater has become an important environmental issue.

Many methods have been reported to remove heavy metal ions from wastewater, such as chemical precipitation $^{4}$, coagulation $^{5}$, ion exchange ${ }^{6}$, membrane filtration $^{7-9}$, and electrochemical treatment ${ }^{10,11}$, etc. These methods have been used in many industries with good effects, but all of them have their own shortcomings. Chemical precipitation may increase the difficulty of recycling metal sludge generated after wastewater treatment. Ion exchange occurs when the adsorption of heavy metal ions by resin is easily restricted by other variable factors. These limitations have severely affected the large-scale application of ion exchange resins in wastewater treatment. Membrane filtration can reduce the amount of chemicals used and the output of metal sludge, but the maintenance cost is too high, the membrane replacement cycle is short, and the waste membrane pollutants

\footnotetext{
${ }^{1}$ School of Metallurgy \& Environment, Central South University, Changsha 410083, Hunan, China. ${ }^{2}$ Dongjiang Environmental Co., Ltd., Shenzhen 518057, Guangdong, China. ${ }^{3}$ Jiangxi Ganchang Evaluation and Testing Technology Consulting Co., Ltd., Nanchang 330063, Jiangxi, China. ${ }^{4}$ Postdoctoral Mobile Station of Central South University, Changsha 410083, Hunan, China. ${ }^{5}$ Shandong Humon Smelting Co. Ltd., Yantai 264109, Shandong, China. ${ }^{\square}$ email: wzbing@126.com; zhaozongw@126.com
} 
generated need further disposal. Electrochemical wastewater technology requires a relatively large capital investment and expensive power supply, and the low purification efficiency is gradually unable to meet the needs of the industry, making it difficult to achieve wide-ranging applications. Carbon nanotubes (CNTs) have attracted great attention in the wastewater purification of heavy metal ions due to their large specific surface area, small size, hollow, layered structure, etc. Li and Wang ${ }^{12,13}$ found that the adsorption capacity of prepared aligned carbon nanotubes (ACNTs) for fluoride ions could reach more than $4.5 \mathrm{mg} / \mathrm{g}$, when studing the adsorption and removal of inorganic $\mathrm{F}^{-}$anions by $\mathrm{CNTs}$. $\mathrm{Liu}^{14}$ used carbon nanotube/calcium alginate (CNTs/CA) composites to remove copper in aqueous solution. When the equilibrium concentration of copper ions reached $5 \mathrm{mg} / \mathrm{L}$, the best adsorption capacity of CNTs/CA for copper ions was $67.9 \mathrm{mg} / \mathrm{g}$. $\mathrm{Li}^{15}$ studied the effect of the morphology of oxidized carbon nanotubes (OCNTs) on the removal of $\mathrm{Pb}$ (II). The results showed that the adsorption capacity of OCNTs for $\mathrm{Pb}$ (II) was closely related to their morphology, and the adsorption capacity of CNTs after oxidation was significantly better than that of CNTs because there were fewer defects. Peng ${ }^{16}$ used carbon nanotube-iron oxide magnetic composites as adsorbents for the removal of $\mathrm{Pb}(\mathrm{II})$ and $\mathrm{Cu}$ (II) from water, and the maximum adsorption capacities were 0.51 and $0.71 \mathrm{mmol} / \mathrm{g}$, respectively. Pillay ${ }^{17}$, Gupta ${ }^{18}$ and Huang ${ }^{19}$ studied the adsorption capacity of three adsorbents, activated carbon, modified multi-walled carbon nanotubes (MWCNTs) and unfunctionalized MWCNTs, to remove low concentrations of $\mathrm{Cr}(\mathrm{VI})$ and found that the adsorption capacity of the unfunctionalized MWCNTs was the best, while the adsorption effect of activated carbon was the worst. Alok Mittal ${ }^{20}$ prepared $\mathrm{MWCNTs} / \mathrm{ThO}_{2}$ nanocomposites and removed $\mathrm{Pb}$ (II) metal from aqueous media. Visibly, CNTs have high efficiency in adsorbing and removing metal ions, but they are difficult to separate from aqueous solutions due to their small size, and are easily discharged into the water environment, causing secondary pollution ${ }^{21}$. Therefore, how to quickly and conveniently solve the problem of difficult separation of CNTs from adsorbed heavy metals urgently needs to be further researched.

In this paper, MWCNTs were first partially oxidized by wet chemicals to load oxygen atoms on the surface to form $6 \mathrm{O}-\mathrm{MWCNTs}$, and then recombined with magnetic ions to give them certain supermagnetic properties. Through modification, a new type of adsorbent, namely, 6O-MWCNTs@ $\mathrm{Fe}_{3} \mathrm{O}_{4}$, could be obtained and used to remove heavy metals in wastewater. This adsorbent enhanced the adsorption capacities of CNTs for heavy metal ions. Meanwhile, the modified CNTs had certain magnetic properties, which were beneficial to the subsequent magnetic separation of CNTs and the recovery of metal resources. First, the surface of CNTs was modified by the wet chemical oxidation method, and later, further processed by solvothermal methods to prepare6O-MWCNTs@ $\mathrm{Fe}_{3} \mathrm{O}_{4}$ with excellent heavy metal adsorption performance. The adsorption performance was checked through multiple factor comparative experiments. Then, the adsorption mechanism and microstructural changes and were studied in-depth through the joint analysis methods of Fourier-transform infrared spectroscopy (FTIR), $\mathrm{X}$-ray photoelectron spectroscopy (XPS), and X-ray diffraction (XRD), and physical property measurement system (PPMS). Changes in the microscopic morphology of 6O-MWCNTs before and after modification were analyzed by scanning electron microscope and transmission electron microscope (SEM-TEM). These data provide a new type of recyclable adsorbent for the efficient treatment of heavy metal ions in wastewater and enrich relevant theoretical knowledge.

\section{Experimental and analytical methods}

Materials. The MWCNTs ( $>97 \mathrm{wt}$. \%) used in the experiment were supplied by the Chinese Academy of Sciences Chengdu Organic Chemistry Co., Ltd.. Other analytical reagents, such as sulfuric acid $\left(\mathrm{H}_{2} \mathrm{SO}_{4}, 98\right.$ vol. $\%)$, nitric acid $\left(\mathrm{HNO}_{3}, 65\right.$ vol. \%), ethylene glycol $\left(\mathrm{C}_{2} \mathrm{H}_{6} \mathrm{O}_{2}\right)$, absolute ethanol $\left(\mathrm{C}_{2} \mathrm{H}_{6} \mathrm{O}\right)$, ferric chloride hexahydrate $\left(\mathrm{FeCl}_{3} \cdot 6 \mathrm{H}_{2} \mathrm{O}, 99\right.$ wt. \%), sodium acetate $\left(\mathrm{CH}_{3} \mathrm{COONa} \cdot 3 \mathrm{H}_{2} \mathrm{O}, 99 \mathrm{wt}\right.$ \% $)$, and sodium hydroxide $(\mathrm{NaOH}, 99$ wt. \%) were provided by Sinopharm Chemical Reagent Beijing Co., Ltd.. The mixed solution containing $\mathrm{Cu}(\mathrm{II})$, $\mathrm{Zn}(\mathrm{II}), \mathrm{Cd}(\mathrm{II}), \mathrm{Ni}(\mathrm{II})$ and $\mathrm{Pb}(\mathrm{II})$ metal ions used in the adsorption experiment was configured according to the corresponding standard and the concentration requirements. The initial ion concentration of the $\mathrm{Pb}$ (II) solution used in the adsorption experiment was $50 \mathrm{mg} / \mathrm{L}$.

\section{Modification of functional groups on the surface of 60-MWCNTs.}

(1) Preparation of 6O-MWCNTs

One gram of MWCNTs was accurately weighed, and thoroughly mixed with $12 \mathrm{ml}$ of concentrated $\mathrm{HNO}_{3}$ ( 65 vol. \%) and $36 \mathrm{ml}$ of $\mathrm{H}_{2} \mathrm{SO}_{4}(98 \mathrm{vol}$. \%) in a $100 \mathrm{ml}$ three-necked round-bottom flask. The mixture was heated to $75^{\circ} \mathrm{C}$ and stirred for $6.0 \mathrm{~h}$ to obtain 6O-MWCNTs. To remove the unreacted impurities on the surface of the modified MWCNTs, the obtained materials were purified in two steps with deionized water and absolute ethanol: (1) The mixed products were washed with deionized water and absolute ethanol three times each, ultrasonicated for $30 \mathrm{~min}$, centrifuged at 10,000 r/min for $10 \mathrm{~min}$. (2) The supernatant was removed, and the bottom black powder was vacuum-dried for $12.0 \mathrm{~h}$ to obtain the surface modified materials, namely, 6O-MWCNTs. Finally, the product was ground, sieved, sealed, and used as the raw material to load magnetic nanoparticles to prepare6O-MWCNTs@ $\mathrm{Fe}_{3} \mathrm{O}_{4}$.

(2) Grafting magnetic nanoparticles on the surface of $6 \mathrm{O}-\mathrm{MWCNTs}$

$\mathrm{FeCl}_{3} \cdot 6 \mathrm{H}_{2} \mathrm{O}(1.73 \mathrm{~g})$ was weighed and mixed with $\mathrm{C}_{2} \mathrm{H}_{6} \mathrm{O}_{2}(35 \mathrm{ml})$ in a $100 \mathrm{ml}$ glass beaker, which was

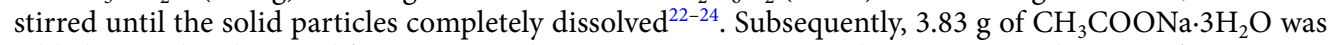
added, stirred and reacted for $30 \mathrm{~min}$ to obtain nanomagnetic particles (Eqs. 1-2). Then, $1 \mathrm{~g}$ of $6 \mathrm{O}-\mathrm{MWC}-$ NTs was added to the mixture, and stirred for $30 \mathrm{~min}$. Later, the mixed solution was transferred to a $100 \mathrm{ml}$ polytetrafluoroethylene lined stainless steel autoclave, reacted at $200{ }^{\circ} \mathrm{C}$ for $8.0 \mathrm{~h}$, and then naturally cooled to room temperature (Eq. 3). The product was washed repeatedly with deionized water and absolute ethanol. 


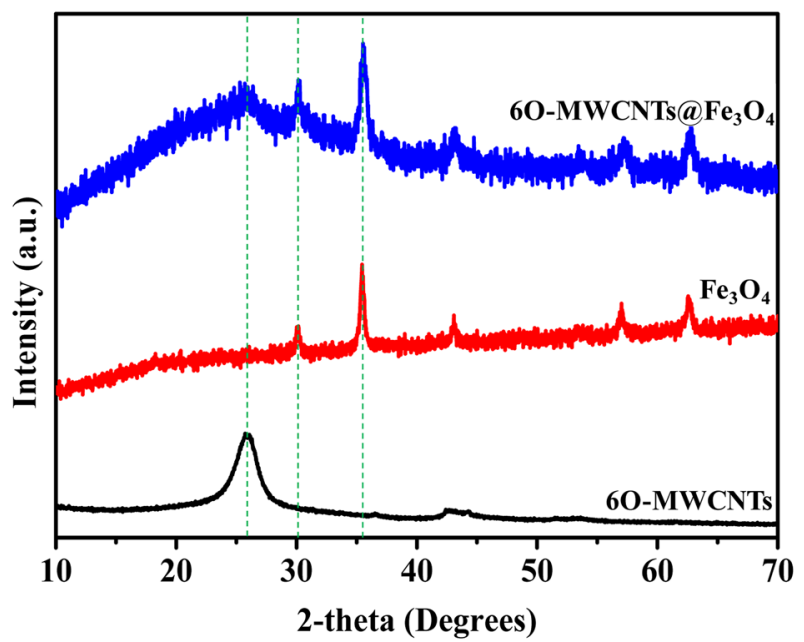

Figure 1. XRD patterns of 6O-MWCNTs, $\mathrm{Fe}_{3} \mathrm{O}_{4}$ and 6O-MWCNTs@ $\mathrm{Fe}_{3} \mathrm{O}_{4}$.

Finally, the magnetic black solid was separated by an external magnet, and the separated black powder was placed in a vacuum drying oven at $80{ }^{\circ} \mathrm{C}$ for $12.0 \mathrm{~h}$ to obtain $6 \mathrm{O}-\mathrm{MWCNTs} @ \mathrm{Fe}_{3} \mathrm{O}_{4}$.

$$
\begin{aligned}
& \mathrm{FeCl}_{3} \cdot 6 \mathrm{H}_{2} \mathrm{O}_{(\mathrm{s})}+3 \mathrm{CH}_{3} \mathrm{COONa}(\mathrm{s})+\mathrm{C}_{2} \mathrm{H}_{6} \mathrm{O}_{2(\mathrm{l})} \rightarrow \mathrm{Fe}(\mathrm{OH})_{3(\mathrm{~s})}+3 \mathrm{NaCl}_{(\mathrm{s})}+3 \mathrm{CH}_{3} \mathrm{COOH}_{(\mathrm{l})}+\mathrm{C}_{2} \mathrm{H}_{6} \mathrm{O}_{2(\mathrm{l})}+3 \mathrm{H}_{2} \mathrm{O}_{(\mathrm{l})} \\
& \mathrm{Fe}(\mathrm{OH})_{3(\mathrm{~s})}+\mathrm{C}_{2} \mathrm{H}_{6} \mathrm{O}_{2(\mathrm{l})} \rightarrow \mathrm{Fe}(\mathrm{OH})_{2(\mathrm{~s})}+\mathrm{C}_{2} \mathrm{H}_{4} \mathrm{O}_{(\mathrm{l})}+\mathrm{H}_{2} \mathrm{O}_{(\mathrm{l})}+\mathrm{OH}_{(\mathrm{aq})}^{-} \\
& 2 \mathrm{Fe}(\mathrm{OH})_{3(\mathrm{~s})}+\mathrm{Fe}(\mathrm{OH})_{2(\mathrm{~s})}+6 \mathrm{O}-\text { MWCNTs } \rightarrow 6 \mathrm{O}-\mathrm{MWCNTs} @ \mathrm{Fe}_{3} \mathrm{O}_{4(\mathrm{~s})}+4 \mathrm{H}_{2} \mathrm{O}_{(\mathrm{l})}
\end{aligned}
$$

Adsorption performance experiment. 6O-MWCNTs@ $\mathrm{Fe}_{3} \mathrm{O}_{4}(20 \mathrm{mg})$ and $100 \mathrm{ml}$ of the metal ion preparation solution were measured and placed into a $250 \mathrm{ml}$ conical flask. The reaction was shaken at $25^{\circ} \mathrm{C}$ and $180 \mathrm{rpm}$ for $60 \mathrm{~min}$. After adsorption reached equilibrium, the mixed liquid was filtered and diluted. Then, the concentration of the heavy metal ions was measured using atomic absorption spectrometry (AAS), and the adsorption capacity was calculated by using the following formula:

$$
\mathrm{Q}_{\mathrm{e}}=\frac{\mathrm{C}_{0} \mathrm{~V}-\mathrm{C}_{\mathrm{e}} \mathrm{V}}{\mathrm{M}}
$$

$\mathrm{Q}_{\mathrm{e}}(\mathrm{mg} / \mathrm{g})$ : adsorption capacity; $\mathrm{C}_{0}(\mathrm{mg} / \mathrm{l})$ : the initial concentrations of the metal ion preparation solution; $\mathrm{C}_{\mathrm{e}}$ $(\mathrm{mg} / \mathrm{l})$ : the equilibrium concentrations of of metal ion; $\mathrm{V}(\mathrm{ml})$ : volume of the metal ion configuration solution; $\mathrm{M}(\mathrm{g})$ : the adsorbent dose of 6O-MWCNTs@ $\mathrm{Fe}_{3} \mathrm{O}_{4}$.

Analytical methods. The phase composition and crystal form of samples were determined by using XRD $(\mathrm{D} / \mathrm{max} 2550 \mathrm{VB})+\mathrm{X}$ with $\mathrm{Cu}$ radiation $(40 \mathrm{kV}, 300 \mathrm{~mA})$; data were collected with a step size of $10^{\circ} / \mathrm{min}$ for $2 \theta$ values ranging from $10^{\circ}$ to $80^{\circ 25,26}$. The concentration of each heavy metal ion in the solution before and after the reaction was determined by AAS (ContrAA 700, Jena Instrument Co., Ltd., Germany). The surface chemistry of samples was studied by XPS with a Thermo Scientific ESCALAB 250Xi spectrometer using an Al Ka X-ray source $(1486.6 \mathrm{eV})$. To compensate for the charging effects, all of the spectra were calibrated with graphitic carbon as a reference at a binding energy (BE) of $284.8 \mathrm{eV}$. The $\mathrm{O} 1 \mathrm{~s}$ spectra were deconvolved with the subtraction of linear background and with a Gaussian (80\%)-Lorentzian (20\%) mixed function. Magnetic properties were detailed by physical property measurement system (PPMS, Quantum Design, USA) at room temperature. FTIR spectra were collected in the range of $400-2000 \mathrm{~cm}^{-1}$ using a Nicolet IS10 spectrometer with $4 \mathrm{~cm}^{-1}$ resolution. The micromorphology and microstructures changes were observed by SEM and TEM (SEM, JEOL JSM-6360LV instrument; TEM, Philips TECNAI-20, Netherlands).

\section{Results and discussion}

Characterization of 60-MWCNTs@ $\mathrm{Fe}_{3} \mathrm{O}_{4} . \quad$ XRD analysis. XRD was used to resolve the phase and crystal changes of 6O-MWCNTs after magnetic grafting, and the results are shown in Fig. 1. 6O-MWCNTs have two typical characteristic peaks, which are located at $25.9^{\circ}$ and $43.6^{\circ}$, and are consistent with those reported in the literature ${ }^{19}$. However, after grafting magnetic nanoparticles onto the surface of $6 \mathrm{O}-\mathrm{MWCNTs}$, the peak of $6 \mathrm{O}-\mathrm{MWCNTs}$ weakens in intensity, and the characteristic peak corresponding to $\mathrm{Fe}_{3} \mathrm{O}_{4}$ appears. The background noise peak of 6O-MWCNTs@ $\mathrm{Fe}_{3} \mathrm{O}_{4}$ is obviously more intense than that of $6 \mathrm{O}-\mathrm{MWCNTs}$, indicating that 


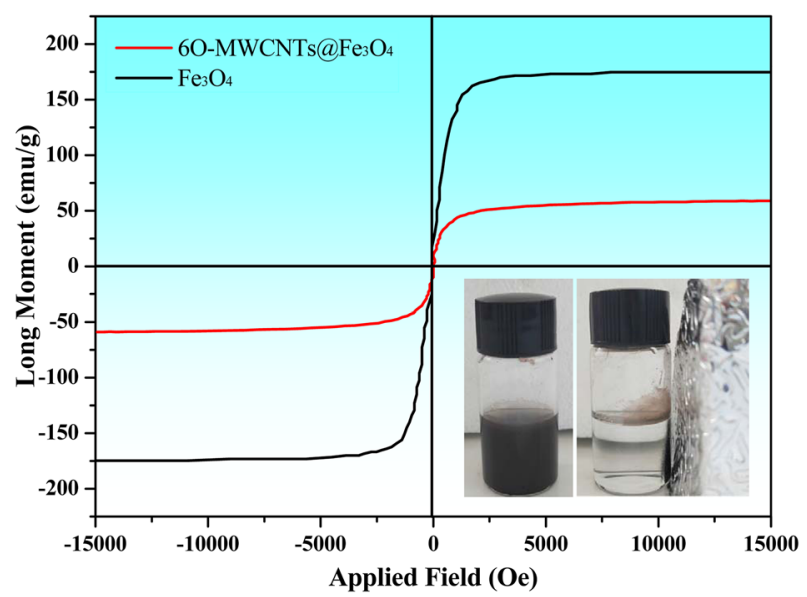

Figure 2. Changes in the hysteresis loop of 6O-MWCNTs loaded with magnetic ions.

the $\mathrm{Fe}_{3} \mathrm{O}_{4}$ on grafted the surface of $6 \mathrm{O}$-MWCNTs is basically in an amorphous state. The figure shows that $\mathrm{Fe}_{3} \mathrm{O}_{4}$ and 6O-MWCNTs coexist in the magnetic MWCNTs.

BET analysis. The textural characteristics of the 6O-MWCNTs are shown in Figure S1. In the low-pressure section, the adsorption capacity of the 6O-MWCNTs adsorbent increases slightly, but there is a sudden increase in the adsorption capacity at approximately $p / p_{0}=0.6 \sim 0.8$. The position of this segment can reflect the pore size of the sample and can be used as a basis for measuring the uniformity of the mesopores. In addition, at higher $p / p_{0}$ vaules, the desorption isotherm does not coincide with the adsorption isotherm, and the desorption isotherm is above the adsorption isotherm. According to the type of mesoporous hysteresis loop ${ }^{27}$, the curve is identified as an $\mathrm{H} 3$ type hysteresis loop, and the existence of a hysteresis loop indicates that MWCNTs form a large number of mesopores after partial oxidation, which is conducive to the formation of more adsorption sites.

Magnetic property. The change in the magnetic property of 6O-MWCNTs after grafting with magnetic particles is shown in Fig. 2. As indicated in Fig. 2, there is almost immeasurable remanence and coercivity, which demonstrate that pure $\mathrm{Fe}_{3} \mathrm{O}_{4}$ and 6O-MWCNTs@ $\mathrm{Fe}_{3} \mathrm{O}_{4}$ show typical superparamagnetic behavior. Moreover, the saturation magnetizations of the as-prepared $\mathrm{Fe}_{3} \mathrm{O}_{4}$ and 6O-MWCNTs@ $\mathrm{Fe}_{3} \mathrm{O}_{4}$ were $176.01 \mathrm{emu} / \mathrm{g}$ and $59.46 \mathrm{emu} / \mathrm{g}$, respectively, as estimated using PPMS at room temperature. This saturation magnetization of 6O-MWCNTs@ $\mathrm{Fe}_{3} \mathrm{O}_{4}$ is lower than that of pure $\mathrm{Fe}_{3} \mathrm{O}_{4}$, which may be attributed to the impact of macromolecules and carbonbased materials in composites. Generally, nanoparticles with saturation magnetizations of $16.3 \mathrm{emu} / \mathrm{g}$ could be separated magnetically from solution using a magnet. Thus, the 6O-MWCNTs@ $\mathrm{Fe}_{3} \mathrm{O}_{4}$ prepared in this study are easily separated from aqueous solutions, and can possibly be ideal adsorbents and carrier. 6O-MWCNTs@ $\mathrm{Fe}_{3} \mathrm{O}_{4}$ can achieve high-efficiency separation through an external magnetic field after selective adsorption of lead ions.

FTIR analysis. To further investigate the changes in the surface functional groups of 6O-MWCNTs, FTIR was used to compare and analyze the samples after grafting, as shown in Fig. 3. After grafting magnetic particles on the surface of 6O-MWCNTs, the positions of the peak corresponding to the functional groups on 6O-MWCNTs are basically unchanged, but the peak intensity is significantly enhanced. The strong peak at $3425 \mathrm{~cm}^{-1}$ is assigned to the $-\mathrm{OH}$ stretching mode of the $\mathrm{COOH}$ group ${ }^{28,29}$, while the characteristic absorption peak located at $1630 \mathrm{~cm}^{-1}$ is assigned to the $\mathrm{C}=\mathrm{O}$ stretching of the $\mathrm{COOH}$ group ${ }^{30,31}$. The characteristic absorption peak at $1386 \mathrm{~cm}^{-1}$ is attributed to $\mathrm{C}-\mathrm{OH}$ stretching ${ }^{32,33}$. In particular, a new peak appearing at $664 \mathrm{~cm}^{-1}$ is caused by $\mathrm{Fe}-\mathrm{O}$ bond tensile vibrations ${ }^{34,35}$. According to the comparison results, the formed 6O-MWCNTs@Fe $\mathrm{O}_{4}$ not only retains the inherent functional groups $(\mathrm{C}=\mathrm{O},-\mathrm{OH}$, and $\mathrm{C}-\mathrm{OH})$ of $6 \mathrm{O}-\mathrm{MWCNTs}$, but also presents new bonds $(\mathrm{Fe}-\mathrm{O})$ corresponding to the magnetic particles.

SEM-TEM analysis. The generation of 6O-MWCNTs@ $\mathrm{Fe}_{3} \mathrm{O}_{4}$ is further proven by the differences and changes in the microscopic morphologies of the product and raw material (shown in Fig. 4). 6O-MWCNTs have a typical tubular structure with a small diameter, and the tubes will entangle with each other to form a similar fishnetlike structure (Fig. 4a). $\mathrm{Fe}_{3} \mathrm{O}_{4}$ nanoparticles show a quasispherical morphology, and their sizes are almost uniformly distributed (Fig. 4b). After mixing with magnetic particles, a large number of spherical particles appear on the surface of the 6O-MWCNTs (Fig. 4c). Tubular 6O-MWCNTs are similar to a needle thread connecting magnetic particles in series. In addition, TEM images of 6O-MWCNTs and 6O-MWCNTs@Fe $\mathrm{O}_{4}$ are shown in Fig. 4. Before the 6O-MWCNTs are loaded with magnetic ions, the shape of the MWCNTs and 6O-MWCNTs had an irregular line-like morphology with a smooth surface (Fig. 4d, e). However, interestingly, after the intervention of magnetic particles, many quasi-spherical granules with an average particle size of $20 \mathrm{~nm}$ are unevenly distributed on the surface of the carbon nanotubes (Fig. 4f). These results further demostrate that $\mathrm{Fe}_{3} \mathrm{O}_{4}$ and 6O-MWCNTs coexist in 6O-MWCNTs@ $\mathrm{Fe}_{3} \mathrm{O}_{4}$. 


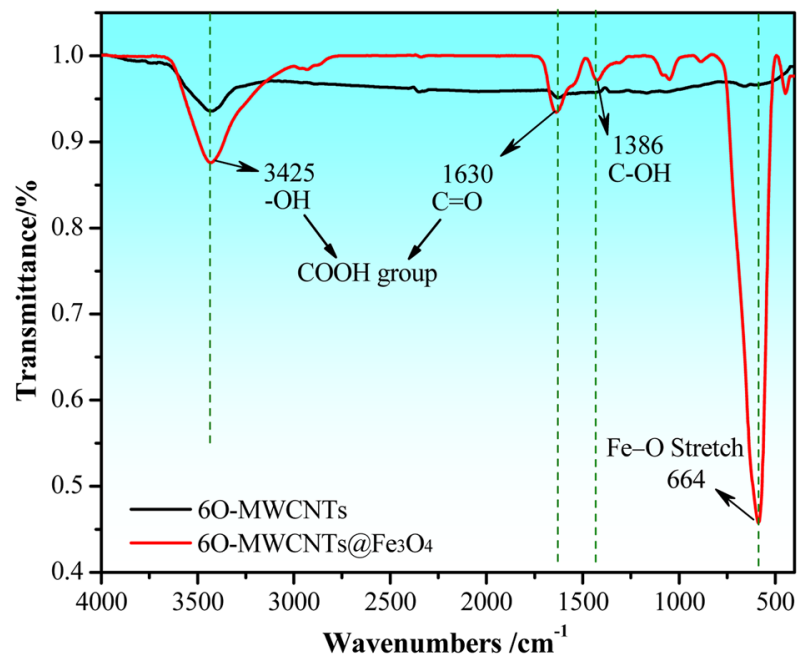

Figure 3. FTIR spectras of 6O-MWCNTs and 6O-MWCNTs@ $\mathrm{Fe}_{3} \mathrm{O}_{4}$.
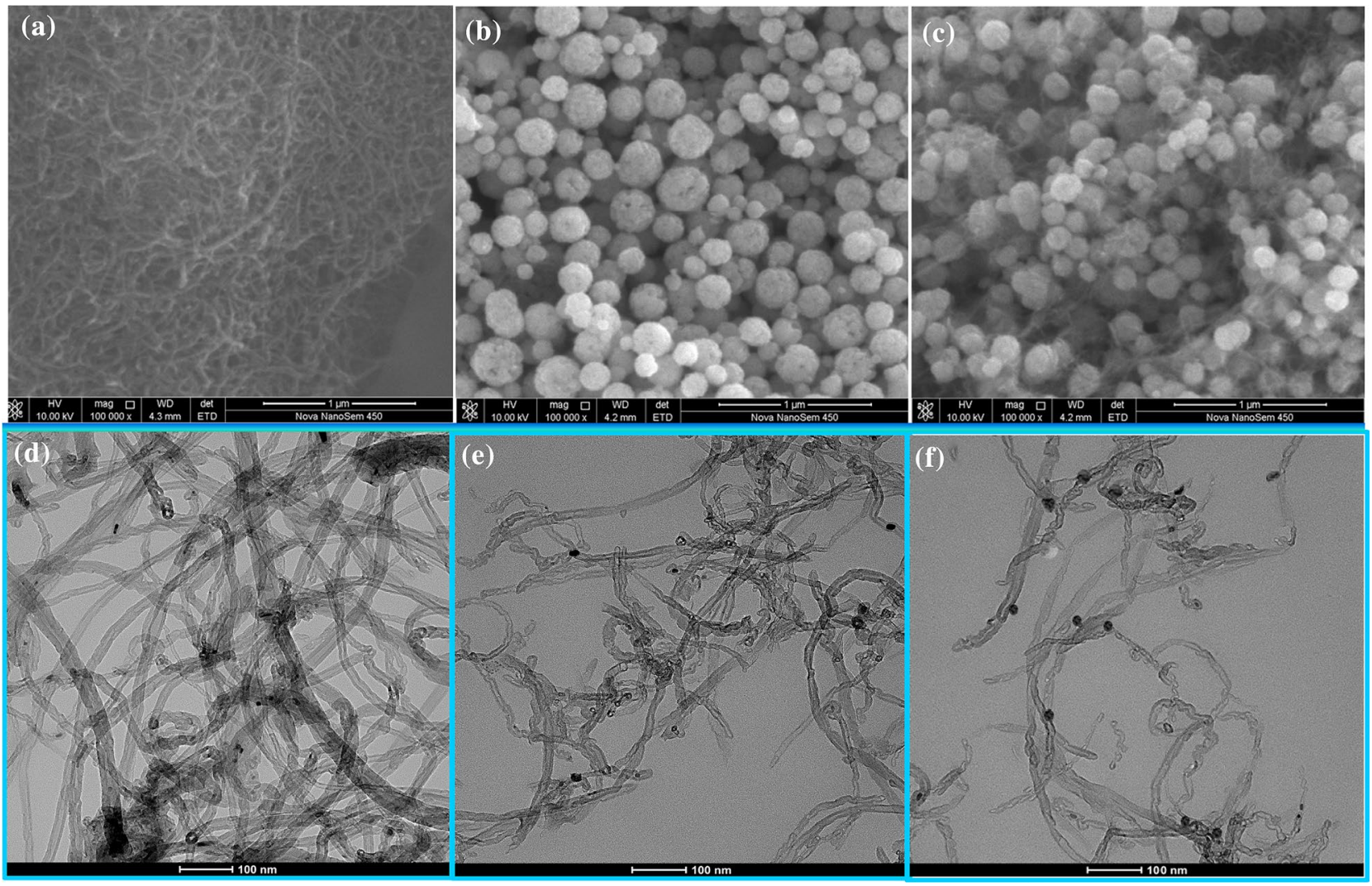

Figure 4. SEM images of 6O-MWCNTs (a), pure $\mathrm{Fe}_{3} \mathrm{O}_{4}(\mathbf{b})$, and 6O-MWCNTs@ $@ \mathrm{Fe}_{3} \mathrm{O}_{4}(\mathbf{c})$ and TEM images of MWCNTs (d), 6O-MWCNTs (e), and 6O-MWCNTs@Fe $\mathrm{O}_{4}(\mathbf{f})$.

\section{Adsorption performance.}

(1) Effect of $\mathrm{pH}$ on the adsorption performance

The adsorption performance of $6 \mathrm{O}-\mathrm{MWCNTs} @ \mathrm{Fe}_{3} \mathrm{O}_{4}$ on metal ions at different $\mathrm{pH}$ is shown in Fig. 5. Before grafting magnetic particles on the surface of $6 \mathrm{O}-\mathrm{MWCNTs}$, a certain adsorption effect on $\mathrm{Pb}(\mathrm{II})$, $\mathrm{Cu}$ (II) and $\mathrm{Cd}(\mathrm{II})$ is observed, among which the adsorption effect on $\mathrm{Pb}$ (II) is the best. The maximum adsorption capacity is $96.09 \mathrm{mg} / \mathrm{g}$, when $\mathrm{pH}=6$ (Fig. 5a). However, after grafting, with the other conditions unchanged, as the $\mathrm{pH}$ of the solution increases, the adsorption capacities of $6 \mathrm{O}-\mathrm{MWCNTs} @ \mathrm{Fe}_{3} \mathrm{O}_{4}$ for the 

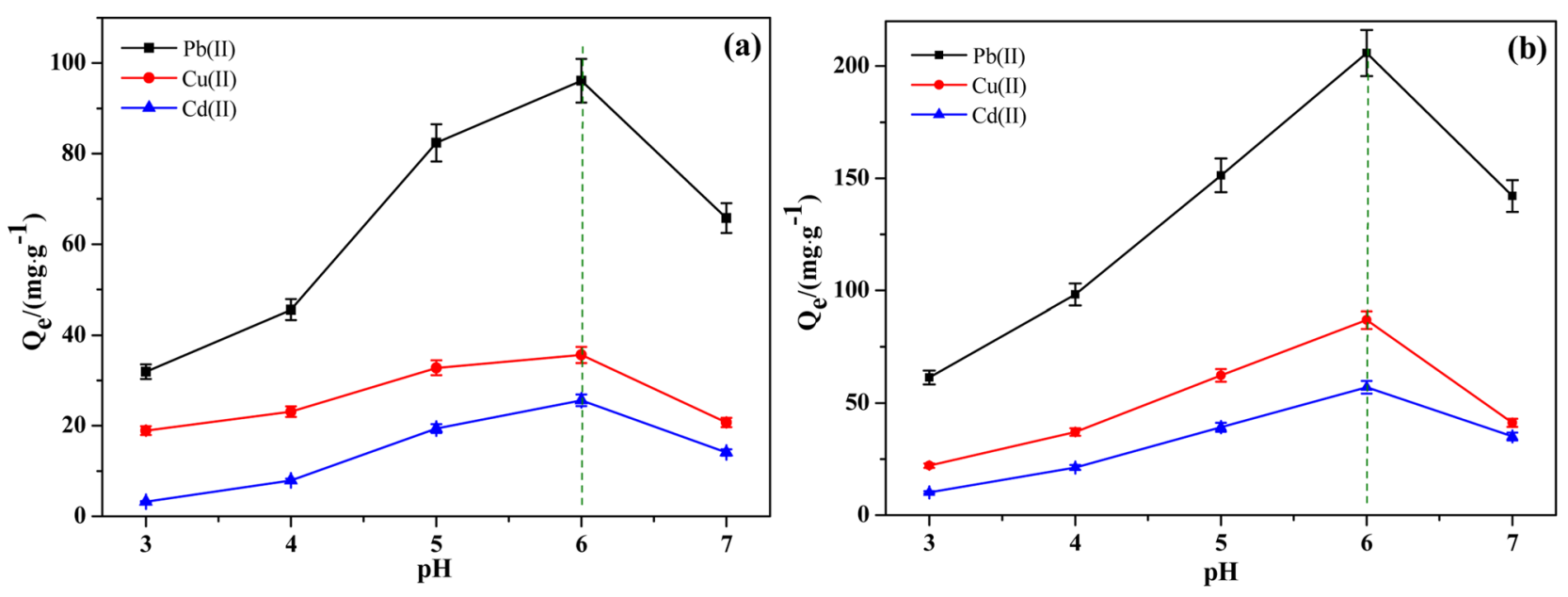

Figure 5. Effect of $\mathrm{pH}$ on the adsorption performance of 6O-MWCNTs (a) and 6O-MWCNTs@Fe $\mathrm{O}_{4}(\mathbf{b})$.
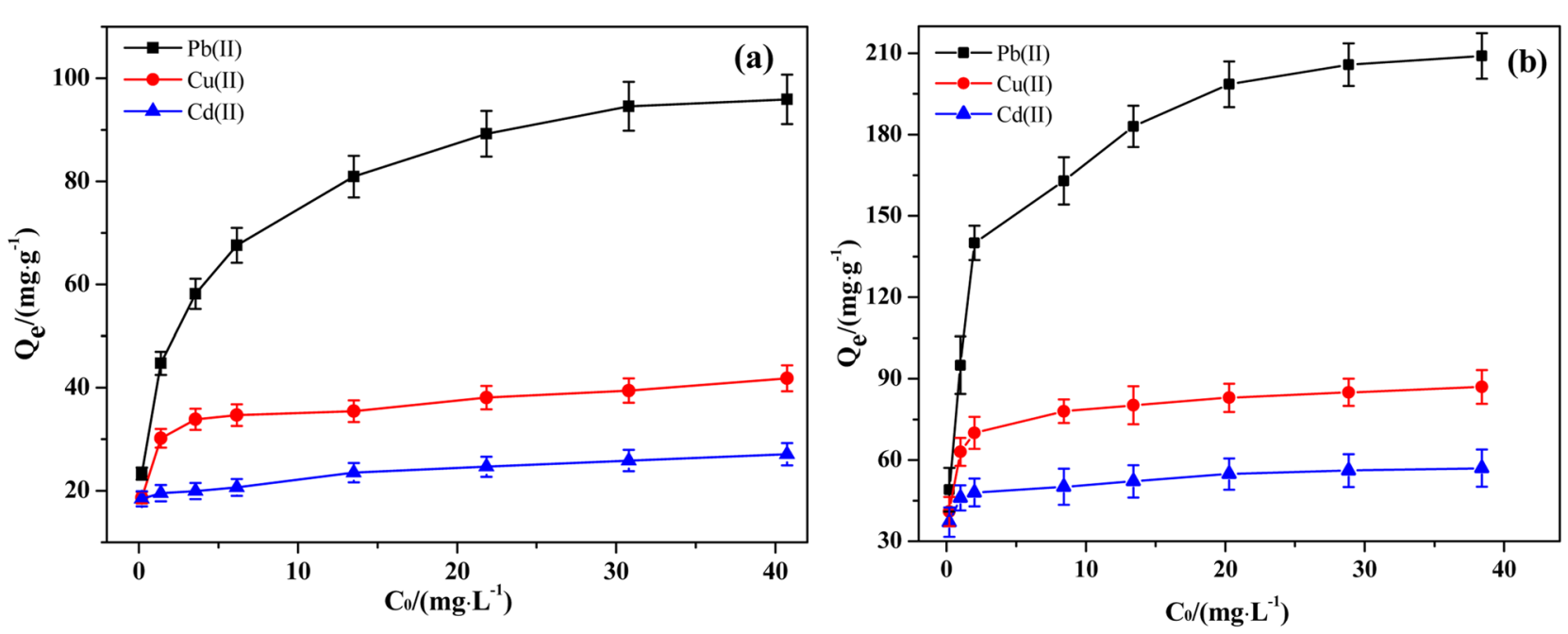

Figure 6. Effect of the initial concentration of metal ions on the adsorption performance of 6O-MWCNTs (a) and6O-MWCNTs@ $\mathrm{Fe}_{3} \mathrm{O}_{4}$ (b).

three metal ions all present a trend of first increasing $(\mathrm{pH} \leq 6)$, and then decreasing $(\mathrm{pH}>6)$. The adsorption effect on $\mathrm{Pb}$ (II) is much better than that on the other two metal ions, with the maximum adsorption capacity reaching $205.8 \mathrm{mg} / \mathrm{g}$ (Fig. 5b), which is much higher than the existing adsorption capacity of the same type of adsorbents, while the adsorption capacities for $\mathrm{Cu}(\mathrm{II})$, and $\mathrm{Cd}(\mathrm{II})$ are only $87.1 \mathrm{mg} / \mathrm{g}, 57.3 \mathrm{mg} / \mathrm{g}$, respectively. The reason for this may be related to the dissociation of the carboxyl group. $\mathrm{H}^{+}$inhibits the dissociation of carboxyl groups and hinders the formation of $\mathrm{O}-$ and $\mathrm{COO}-{ }^{36}$. The increase in $\mathrm{pH}$ means that the $\mathrm{H}^{+}$content in the solution decreases, which will cause the protonation effect of the carboxyl groups on the surface of $6 \mathrm{O}-\mathrm{MWCNTs} @ \mathrm{Fe}_{3} \mathrm{O}_{4}$ to weaken, and the number of adsorption sites on the surface of 6O-MWCNTs@ $\mathrm{Fe}_{3} \mathrm{O}_{4}$ increases, making more carboxyl groups coordinate with metal ions; therefore, the saturation adsorption capacity increases. However, as the $\mathrm{pH}$ further increases, the solution gradually becomes alkaline. According to the metal ion dissolution precipitation curve, when $\mathrm{pH}>5$, although the metal ions in the solution are still mainly adsorbed, some metal ions have begin to precipitate. As the $\mathrm{pH}$ continues to increase, the precipitation trend further intensifies, which is also the reason for the sharp decline in the adsorption effect of 6O-MWCNTs@ $\mathrm{Fe}_{3} \mathrm{O}_{4}$.

(2) Effect of the initial concentration of metal ions

The effect of the initial concentration $\left(C_{0}\right)$ of different metal ions on the adsorption performance of 6O-MWCNTs@Fe $\mathrm{O}_{4}$ is shown in Fig.6. Although the metal ion adsorption curves of 6O-MWCNTs@Fe $\mathrm{O}_{4}$ and 6O-MWCNTs have similar trends, the adsorption capacity of 6O-MWCNTs@ $\mathrm{Fe}_{3} \mathrm{O}_{4}$ is much higher than that of 6O-MWCNTs (Fig. 6a). As the initial concentration of metal ions in the solution increases, the adsorption capacities of $6 \mathrm{O}-\mathrm{MWCNTs} @ \mathrm{Fe}_{3} \mathrm{O}_{4}$ for various metal ions shows an overall upward trend (Fig. 6b). After reaching a certain concentration, the upward trend of the adsorption curve slows down. An increase in the concentration of metal ions means that the absolute content of metal ions per unit volume increases. The chance of metal ions contacting 6O-MWCNTs@ $\mathrm{Fe}_{3} \mathrm{O}_{4}$ increases, resulting in a rapid increase 

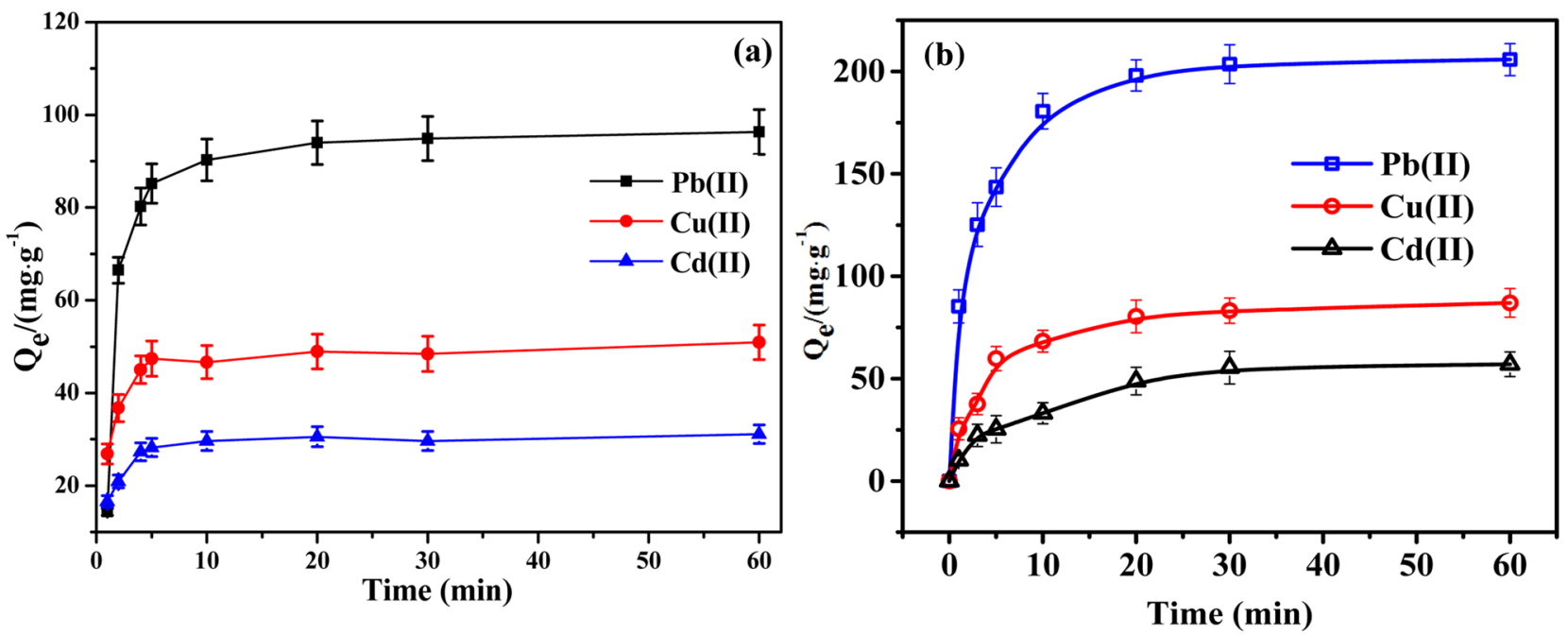

Figure 7. Effect of adsorption time on the adsorption performance of 6O-MWCNTs (a) and 6O-MWCNTs@ $\mathrm{Fe}_{3} \mathrm{O}_{4}(\mathbf{b})$.

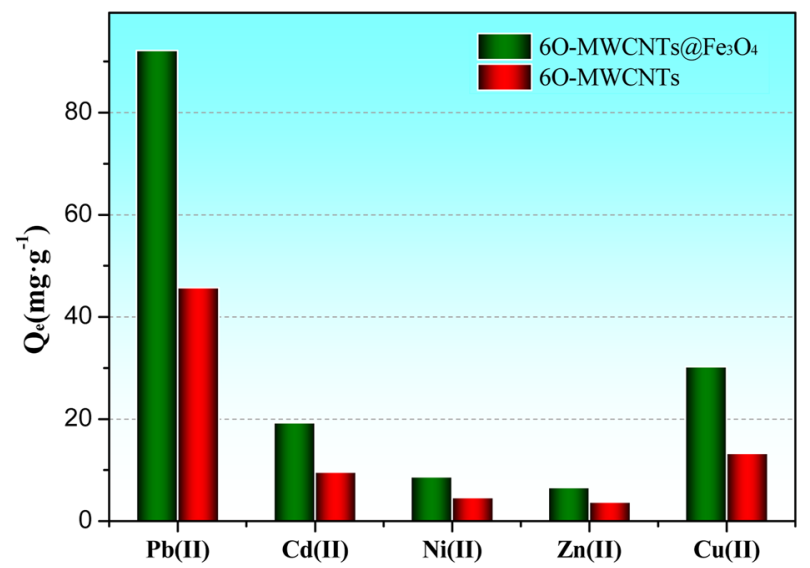

Figure 8. Effect of coexisting metal ions on the adsorption performance of $6 \mathrm{O}-\mathrm{MWCNTs@Fe} \mathrm{O}_{4}$.

in the amount of metal ions adsorbed. However, with a further increase in the initial concentration, the adsorption efficiency of 6O-MWCNTs@ $\mathrm{Fe}_{3} \mathrm{O}_{4}$ for metal ions reaches saturation, and the growth rate of the adsorption curve becomes flat.

(3) Effect of adsorption time

The effect of the adsorption time on the adsorption performance of 6O-MWCNTs@ $\mathrm{Fe}_{3} \mathrm{O}_{4}$ with the other factors being constant is shown in Fig. 7. The adsorption capacity of $\mathrm{Pb}(\mathrm{II}), \mathrm{Cu}(\mathrm{II})$, and $\mathrm{Cd}(\mathrm{II})$ increases rapidly, within $10 \mathrm{~min}$. With a further increase of the adsorption time, although the adsorption capacity continues to increase, the increase is obviously weakened. After $30 \mathrm{~min}$, the adsorption reaction basically reaches equilibrium. The reason for this is related to the adsorption sites on the surface of the adsorbent. In the initial stage, there were enough adsorption sites on the surface of $6 \mathrm{O}-\mathrm{MWCNTs} @ \mathrm{Fe}_{3} \mathrm{O}_{4}$, and the concentration of metal ions was high. Coordination between the adsorption sites and the metal ion has a high success rate, leading to a rapid increase in the adsorption rate in the early stage. However, as the number of adsorption sites decreases, the adsorption capacity of carbon nanotubes is close to saturation. When the adsorption time is prolonged, the absolute adsorption capacity is basically not affected, and the adsorption curve is basically a horizontal line.

(4) Effect of coexisting metal ions

To investigate the adsorption performance of 6O-MWCNTs@ $\mathrm{Fe}_{3} \mathrm{O}_{4}$ in the solution of coexisting metal ions, the carbon nanotubes were mixed with a solution containing $\mathrm{Cd}(\mathrm{II}), \mathrm{Ni}(\mathrm{II}), \mathrm{Zn}$ (II), $\mathrm{Cu}$ (II), and $\mathrm{Pb}$ (II) and multiple ions of the same valence for the adsorption reaction, and the result is shown in Fig. 8 . The adsorption capacity of 6O-MWCNTs@ $\mathrm{Fe}_{3} \mathrm{O}_{4}$ for $\mathrm{Pb}(\mathrm{II})$ reaches $92.2 \mathrm{mg} / \mathrm{g}$, while the adsorption capacity of $\mathrm{Cd}(\mathrm{II}), \mathrm{Ni}(\mathrm{II}), \mathrm{Zn}(\mathrm{II})$, and $\mathrm{Cu}(\mathrm{II})$ only reaches $19.3 \mathrm{mg} / \mathrm{g}, 8.7 \mathrm{mg} / \mathrm{g}, 6.6 \mathrm{mg} / \mathrm{g}$, and $30.2 \mathrm{mg} / \mathrm{g}$, respectively. The adsorption capacity for $\mathrm{Pb}$ (II) is much greater than that forother competing ions. Visibly, under the interference of many same-valent ions, 6O-MWCNTs@ $\mathrm{Fe}_{3} \mathrm{O}_{4}$ have a good selective adsorption effect on lead ions. 

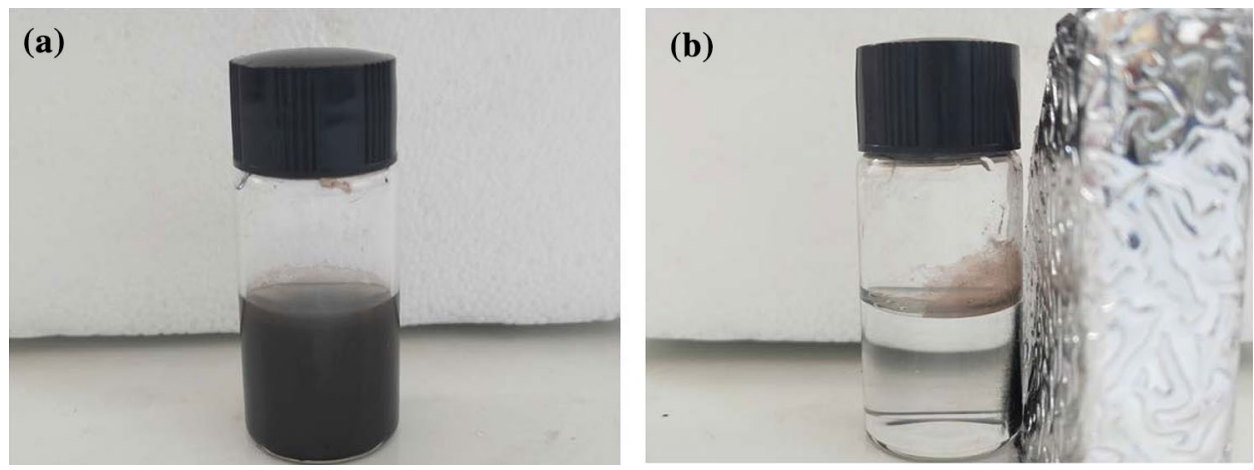

Figure 9. Photo of the 6O-MWCNTs@ $\mathrm{Fe}_{3} \mathrm{O}_{4}$ separation and redispersion process. (a) without an external magnetic field and (b) with an external magnetic field.

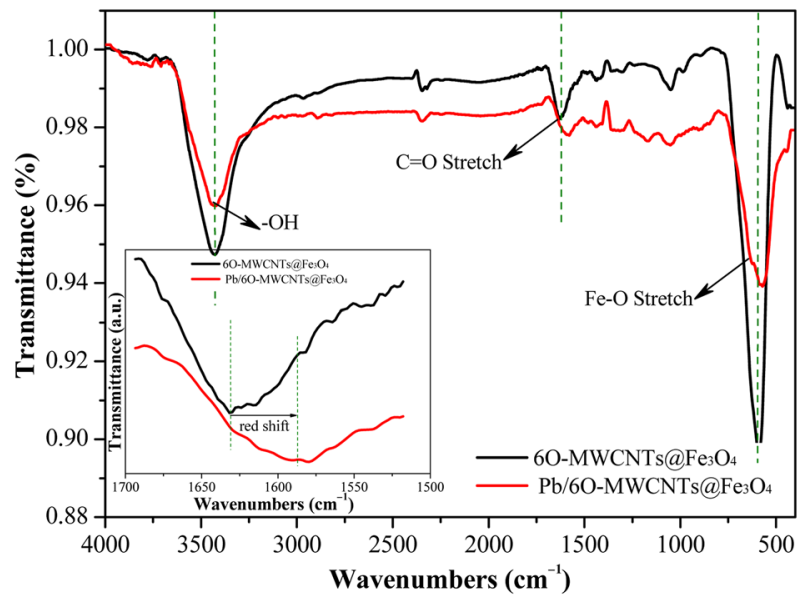

Figure 10. FTIR spectra of 6O-MWCNTs@ $\mathrm{Fe}_{3} \mathrm{O}_{4}$ after $\mathrm{Pb}(\mathrm{II})$ adsorption.

Magnetic separation performance. To study the magnetic separation effect of 6O-MWCNTs@ $\mathrm{Fe}_{3} \mathrm{O}_{4}$ after adsorbing metal ions, a magnetic field was gradually applied to 6O-MWCNTs@ $\mathrm{Fe}_{3} \mathrm{O}_{4}$ saturated with adsorbed metal ions. The comparison results are shown in Fig. 9. After 6O-MWCNTs@ $\mathrm{Fe}_{3} \mathrm{O}_{4}$ adsorbs heavy metals, they are evenly dispersed in the solution to form a suspended turbid liquid when the magnetic field is notapplied. However, the magnetic field gradually approaches, the 6O-MWCNTs@ $\mathrm{Fe}_{3} \mathrm{O}_{4}$ with adsorbed heavy metals migrate in the direction of the magnetic field and finally adhere to the wall, and the solution becomes clear. After the external magnetic field moves away, the separated 6O-MWCNTs@ $\mathrm{Fe}_{3} \mathrm{O}_{4}$ with adsorbed heavy metals and the clarified liquid will become turbid again. These results show that by applying an external magnetic field, 6O-MWCNTs@ $\mathrm{Fe}_{3} \mathrm{O}_{4}$ after the adsorption of heavy metals can be separated quickly from the solutionto recycle metal resources.

Adsorption mechanism. Based on the previous results, 6O-MWCNTs@ $\mathrm{Fe}_{3} \mathrm{O}_{4}$ had good selective adsorption performance in heavy metal-containing wastewater. To ascertain the adsorption mechanism, the changes in functional groups before and after adsorption of $\mathrm{Pb}(\mathrm{II})$ were analyzed by FTIR. The comparison result is shown in Fig. 10. After adsorping $\mathrm{Pb}(\mathrm{II})$, the intensity of vibration absorption peaks corresponding to the functional groups of $-\mathrm{OH}$ and $\mathrm{C}=\mathrm{O}$ in the $\mathrm{COOH}$ group significantly weakens, and the same applies to the $\mathrm{Fe}-\mathrm{O}$ bond in $\mathrm{Fe}_{3} \mathrm{O}_{4}$. The reason for this is that after adsorbing $\mathrm{Pb}(\mathrm{II})$, a new bond forms between the $\mathrm{COOH}$ group and $\mathrm{Pb}(\mathrm{II})$, resulting in a decrease in the relative amount of $\mathrm{COOH}$. In addition, the characteristic peaks of $\mathrm{C}=\mathrm{O}$ and $\mathrm{Fe}-\mathrm{O}$ bonds present a redshift, indicating that the newly formed bond between the $\mathrm{COOH}$ group and $\mathrm{Pb}(\mathrm{II})$ is more stable than $\mathrm{COOH}$, namely, adsorbed ions can stably exist in the solution. In summary, $-\mathrm{OH}$ and $\mathrm{C}=\mathrm{O}$ bonds on the surface of 6O-MWCNTs@ $\mathrm{Fe}_{3} \mathrm{O}_{4}$ may be effective sites for the adsorption of heavy metal ions, and XPS needs to be used to further compare and analyze the changes in the surface chemical state.

Almost all the chemical bonds on the surface of $6 \mathrm{O}-\mathrm{MWCNTs} @ \mathrm{Fe}_{3} \mathrm{O}_{4}$ involve oxygen atoms. Therefore, the changes in $\mathrm{O} 1 \mathrm{~s}$ after $\mathrm{Pb}(\mathrm{II})$ adsorption were further analyzed, and the deconvoluted peak results are shown in Fig. 11. The O1s peak is divided into three peaks at $531.47 \mathrm{eV}, 533.34 \mathrm{eV}$, and $535.31 \mathrm{eV}$, which are assigned to $\mathrm{C}=\mathrm{O}, \mathrm{C}-\mathrm{O}$, and $\mathrm{C}-\mathrm{OH}$ bonds, respectively ${ }^{37,38}$. According to the literature ${ }^{37-40}$, the $\mathrm{O} 1 \mathrm{~s}$ binding energies of $-\mathrm{OH}$, $\mathrm{C}-\mathrm{O}, \mathrm{C}=\mathrm{O}$, and $\mathrm{O}-\mathrm{Pb}(\mathrm{II})$ follow the order $-\mathrm{OH}>\mathrm{C}-\mathrm{O}>\mathrm{C}=\mathrm{O}>\mathrm{O}-\mathrm{Pb}(\mathrm{II})$. Therefore, the O1s shift to a lower 


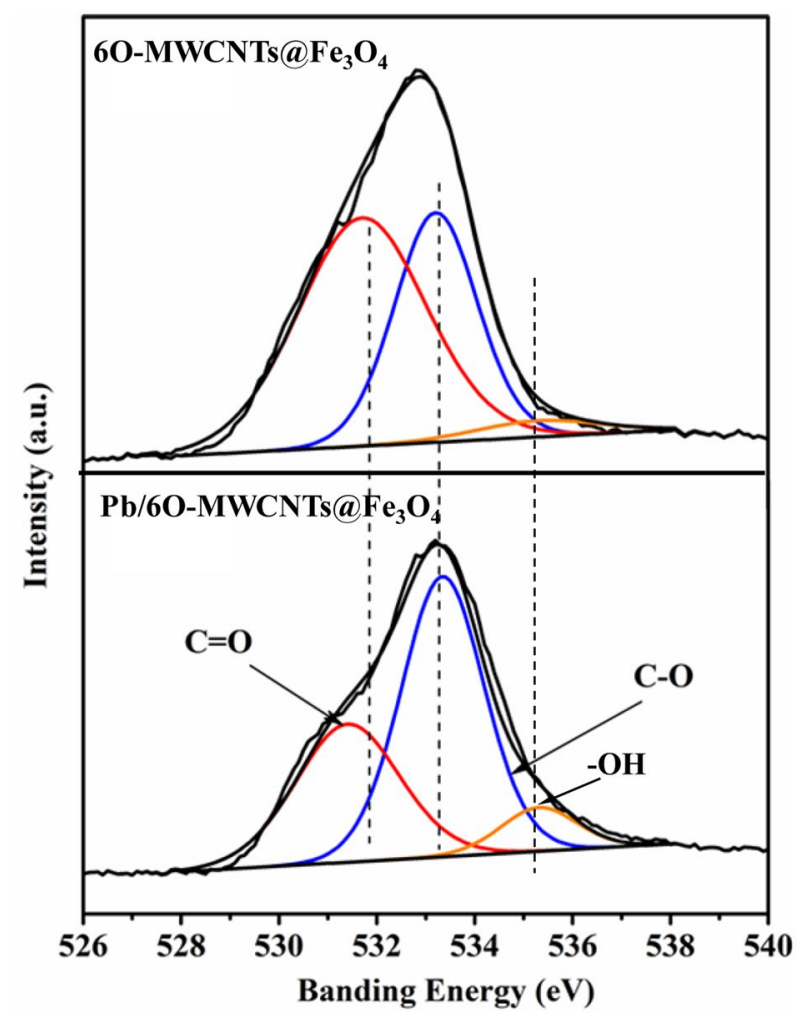

Figure 11. Typical deconvoluted peaks of $\mathrm{O} 1 \mathrm{~s}$ before and after adsorption of $\mathrm{Pb}(\mathrm{II})$.

\begin{tabular}{|c|c|c|c|c|}
\hline \multirow[b]{2}{*}{ Chemical bonds } & \multicolumn{2}{|c|}{ 6O-MWCNTs@Fe ${ }_{3} \mathrm{O}_{4}$} & \multicolumn{2}{|c|}{$\mathrm{Pb} / 6 \mathrm{O}-\mathrm{MWCNTs} @ \mathrm{Fe}_{3} \mathrm{O}_{4}$} \\
\hline & $\mathrm{BE}(\mathrm{eV})$ & Percentage (\%) & $\mathrm{BE}(\mathrm{eV})$ & Percentage (\%) \\
\hline $\mathrm{C}=\mathrm{O}$ & 531.47 & 57.14 & 531.70 & 37.93 \\
\hline $\mathrm{C}-\mathrm{O}$ & 533.34 & 34.68 & 533.21 & 58.04 \\
\hline$-\mathrm{OH}$ & 535.31 & 8.19 & 535.3 & 4.03 \\
\hline
\end{tabular}

Table 1. Peak positions and relative abundance from curve fitting of O1s.

binding energy area is attributed to the formation of new bonds between the functional groups on the surface of 6O-MWCNTs and $\mathrm{Pb}(\mathrm{II})$ through $\mathrm{O}$ atoms. In addition, the corresponding relative contents of $\mathrm{C}=\mathrm{O}$ and $-\mathrm{OH}$ bonds decrease from $57.14 \%$ and $8.19 \%$ to $37.93 \%$ and $4.03 \%$, respectively (Table 1), while the content of C-O bonds increases from $34.68 \%$ to $58.07 \%$. The ratio of $\mathrm{C}=\mathrm{O} / \mathrm{C}-\mathrm{O}$ decreases from 1.65 before adsorption to 0.65 ,

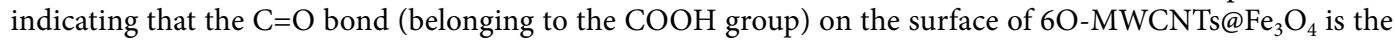
main adsorption site for $\mathrm{Pb}(\mathrm{II})$. That is, after $\mathrm{C}=\mathrm{O}$ adsorbs $\mathrm{Pb}(\mathrm{II})$, the $\mathrm{C}=\mathrm{O}$ double bond is opened and converted into a $\mathrm{C}-\mathrm{O}$ bond and $\mathrm{Pb}-\mathrm{O}$ bond.

Based on the above analysis results, we speculate that the mechanism of 6O-MWCNTs@Fe $\mathrm{O}_{4}$ adsorbing heavy metal ions is as follows: when 6O-MWCNTs recombines with magnetic particles, the COOH group will be loaded on the surface of 6O-MWCNTs@ $\mathrm{Fe}_{3} \mathrm{O}_{4}$, which is composed of two chemical bonds, i. e., $-\mathrm{COOH}$ and $-\mathrm{OH}$ bonds (Fig. 12a). According to Chen's research ${ }^{41}$, the $\mathrm{O}$-containing functional groups $(-\mathrm{COOH},-\mathrm{OH})$ are likely located at tube ends and defect sites on the tube sidewalls. As known, $\mathrm{Pb}$ (II), $\mathrm{Cu}$ (II) and $\mathrm{Cd}(\mathrm{II})$ ions have an empty d orbit, oxygen atom has a lone pair of electron that can bind metal ions through electron pair sharing to form the complex ${ }^{42}$. The hydroxyl $(-\mathrm{OH})$ and carboxyl group (-COOH) on 6O-MWCNTs@ $\mathrm{Fe}_{3} \mathrm{O}_{4}$ is freely available for characteristic coordination bonding with metal ions ${ }^{43}$. The main binding sites are located at the oxygen atom of carboxyl group on the oxygen-containing functional groups on the 6O-MWCNTs@ $\mathrm{Fe}_{3} \mathrm{O}_{4}$ hybrid. $\mathrm{C}=\mathrm{O}$ bond in the $\mathrm{COOH}$ group opens and transforms from covalent bond to an ionic bond, and forms a new $\mathrm{C}-\mathrm{O}-\mathrm{Pb}(\mathrm{II})$ bond (Fig. 12b). The conversion of covalent bonds to ionic bonds is equivalent to $\mathrm{O}$ atoms obtaining an electron cloud. This also explains the shift in the $\mathrm{O} 1 \mathrm{~s}$ peak to a lower binding energy after adsorption of $\mathrm{Pb}(\mathrm{II})$. In addition, hydroxyl group and carboxyl group on 6O-MWCNTs@ $\mathrm{Fe}_{3} \mathrm{O}_{4}$ surface afford deprotonation reaction under a certain $\mathrm{pH}$ value, and the surface charge becomes more negative. The electrostatic attraction may form between the negatively charged functional groups such as $\mathrm{COO}$ - bond and $\mathrm{O}$ - bond on the surface of 6O-MWCNTs@ $\mathrm{Fe}_{3} \mathrm{O}_{4}$ and $\mathrm{Pb}(\mathrm{II}), \mathrm{Cu}$ (II) and $\mathrm{Cd}(\mathrm{II})$ ions ${ }^{44}$. Although the pKsp of COO- and $\mathrm{Pb}$ (II) is smaller than that of $\mathrm{Cu}(\mathrm{II})$, the radius of $\mathrm{Pb}(\mathrm{II})(0.119 \mathrm{~nm})^{45}$ is much larger than that of $\mathrm{Cu}$ (II) $(0.073 \mathrm{~nm})^{46}$ and $\mathrm{Cd}$ (II) 


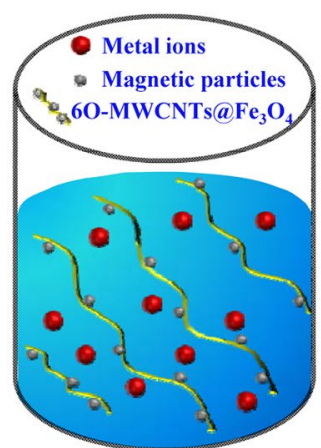

(a) Modification

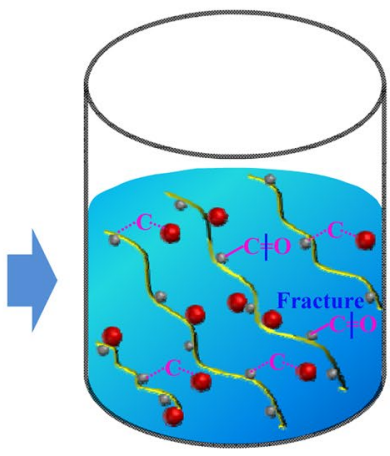

(b) Adsorption

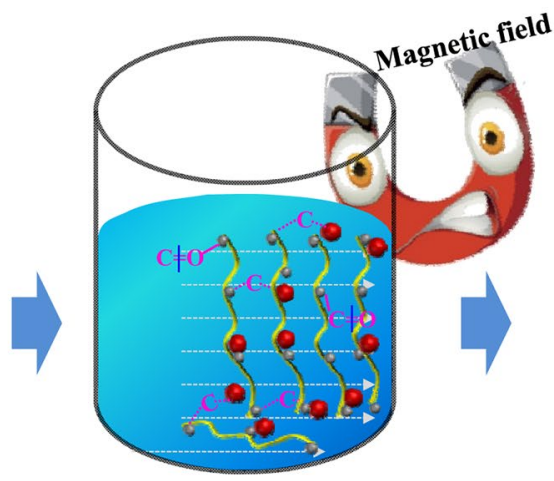

(c) Separation
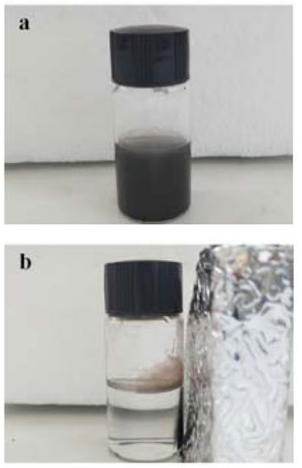

Figure 12. The mechanism of $6 \mathrm{O}-\mathrm{MWCNTs} @ \mathrm{Fe}_{3} \mathrm{O}_{4}$ adsorbing heavy metal ions in wastewater.

\begin{tabular}{|c|c|c|c|c|}
\hline Adsorbents & Metal ions & $\mathrm{Q}_{\max }(\mathrm{mg} / \mathrm{g})$ & $\mathrm{pH}$ & Refs \\
\hline 6O-MWCNTs@Fe $\mathrm{O}_{4}$ & $\mathrm{~Pb}(\mathrm{II})$ & 215.05 & 6.0 & This work \\
\hline $\mathrm{MWCNTs} / \mathrm{ThO}_{2}$ & $\mathrm{~Pb}(\mathrm{II})$ & 178.25 & 5.5 & 20 \\
\hline $50 \% \mathrm{CNTs} / \mathrm{Fe}_{3} \mathrm{O}_{4}$ & $\mathrm{~Pb}(\mathrm{II})$ & 40.88 & 6.2 & 51 \\
\hline CNTs & $\mathrm{Pb}(\mathrm{II})$ & 102.04 & 5.0 & 52 \\
\hline CS-MA-DETA & $\mathrm{Pb}(\mathrm{II})$ & 239.2 & 5.0 & 53 \\
\hline magnetic chitosan with xanthate (XMCS) & $\mathrm{Pb}(\mathrm{II})$ & 76.9 & 5.0 & 54 \\
\hline 6O-MWCNTs@ $\mathrm{Fe}_{3} \mathrm{O}_{4}$ & $\mathrm{Cu}(\mathrm{II})$ & 87.41 & 6.0 & This work \\
\hline $\mathrm{CNTs} / \mathrm{CA}$ & $\mathrm{Cu}(\mathrm{II})$ & 67.9 & 2.1 & 14 \\
\hline $\mathrm{Fe}_{3} \mathrm{O}_{4}$ nanoparticles & $\mathrm{Cu}(\mathrm{II})$ & 35.46 & 4.0 & 55 \\
\hline magnetic chitosan with xanthate (XMCS) & $\mathrm{Cu}(\mathrm{II})$ & 34.5 & 5.0 & 54 \\
\hline$\gamma$-PGA-Fe ${ }_{3} \mathrm{O}_{4}$-GO-(o-MWCNTs) & $\mathrm{Cu}(\mathrm{II})$ & 574.7 & 8.0 & 56 \\
\hline 6O-MWCNTs@Fe $\mathrm{O}_{4}$ & $\mathrm{Cd}(\mathrm{II})$ & 57.18 & 6.0 & This work \\
\hline $\mathrm{Fe}_{3} \mathrm{O}_{4}$ nanoparticles & $\mathrm{Cd}(\mathrm{II})$ & 35.46 & 4.0 & 55 \\
\hline$\gamma$-PGA-Fe ${ }_{3} \mathrm{O}_{4}$-GO-(o-MWCNTs) & $\mathrm{Cd}(\mathrm{II})$ & 625.0 & 5.0 & 56 \\
\hline CS-MA-DETA & $\mathrm{Cd}(\mathrm{II})$ & 201.6 & 5.0 & 53 \\
\hline Microwave assisted MWCNTs & $\mathrm{Cd}(\mathrm{II})$ & 88.62 & 5.0 & 57 \\
\hline
\end{tabular}

Table 2. Comparison of the maximum adsorption capacity of $\mathrm{Cd}(\mathrm{II}), \mathrm{Cu}(\mathrm{II})$ and $\mathrm{Pb}(\mathrm{II})$ ions on various adsorbents.

$(0.095 \mathrm{~nm})^{47}$. The special pore structure of 6O-MWCNT@ $\mathrm{Fe}_{3} \mathrm{O}_{4}$ enables more effective coordination between $-\mathrm{COOH},-\mathrm{OH}$ and $\mathrm{Pb}(\mathrm{II})$, which results in the adsorption effect of $6 \mathrm{O}-\mathrm{MWCNT} @ \mathrm{Fe}_{3} \mathrm{O}_{4}$ on $\mathrm{Pb}(\mathrm{II})$ is far greater than that of $\mathrm{Cu}(\mathrm{II})$ and $\mathrm{Cd}(\mathrm{II})$ (Fig. 12c).. Therefore, under the action of both coordination and electrostatic attraction, the adsorbent exhibits a high selective adsorption capacity for $\mathrm{Pb}(\mathrm{II})$ ion.

Selective adsorption mechanism. Although both FTIR and XPS studies revealed the adsorption mechanism that $\mathrm{Pb}(\mathrm{II}), \mathrm{Cu}(\mathrm{II})$ and $\mathrm{Cd}(\mathrm{II})$ formed complexes with the oxygen atoms of $6 \mathrm{O}-\mathrm{MWCNTs} @ \mathrm{Fe}_{3} \mathrm{O}_{4}$, the mechanism cannot be effectively used to explain the selective adsorption behaviors of $\mathrm{Pb}$ (II), $\mathrm{Cu}$ (II) and Cd(II) on 6O-MWCNTs@ $\mathrm{Fe}_{3} \mathrm{O}_{4}$. Comparing the characteristic properties of $\mathrm{Pb}$ (II), $\mathrm{Cu}$ (II) and $\mathrm{Cd}(\mathrm{II})$, the differences in covalent index $\left(X_{m}^{2} r\right.$, where $X_{m}$ is electronegativity and $r$ is ionic radius) may be the reason causing the selective adsorption of $\mathrm{Pb}(\mathrm{II}), \mathrm{Cu}(\mathrm{II})$ and $\mathrm{Cd}(\mathrm{II})$ by $6 \mathrm{O}-\mathrm{MWCNTs} @ \mathrm{Fe}_{3} \mathrm{O}_{4} . X_{m}^{2} r$ is a measure for a metal ion of the importance of covalent interactions relative to ionic interactions. According to the Nieboer and Richardson ${ }^{31}$, the larger the $X_{m}^{2} r$, the more characteristics of soft acids (HSAB theory), and the metal ions preferentially interacted with the functional group. The covalent index decreased in the following order: $\mathrm{Pb}(6.41)>\mathrm{Cu}(2.98)>\mathrm{Cd}$ $(2.71)^{48}$, suggesting that $\mathrm{Pb}$ (II) has a stronger attraction than $\mathrm{Cu}(\mathrm{II})$ and $\mathrm{Pd}(\mathrm{II})$ to the lone pair of electrons in oxygen atoms to form complexes ${ }^{49}$. Vijayaraghavan et al. ${ }^{50}$ studied the application of sargassum biomass to removal heavy metal ions from synthetic multi-metal ( $\mathrm{Pb}(\mathrm{II}), \mathrm{Cu}(\mathrm{II}), \mathrm{Zn}(\mathrm{II})$ and $\mathrm{Mn}(\mathrm{II})$ ) solutions, they also confirmed that both electronegativity and ionic radii determine the order of preference of metal binding onto alginate.

The removal capacity of 6O-MWCNT@ $\mathrm{Fe}_{3} \mathrm{O}_{4}$ is compared with some of other adsorbents reported in the literature (Table 2). It is seen from the comparison results that the reported different types of adsorbents all have a certain degree of adsorption on metal ions, but the adsorption effect is generally not particularly good. Among them, only $\gamma$-PGA- $\mathrm{Fe}_{3} \mathrm{O}_{4}$-GO-(o-MWCNTs) has a maximum adsorption capacity of $574.7 \mathrm{mg} / \mathrm{g}$ and $625.0 \mathrm{mg} / \mathrm{g}$ 
for $\mathrm{Cu}(\mathrm{II})$ and $\mathrm{Cd}(\mathrm{II})$. The 6O-MWCNTs@ $\mathrm{Fe}_{3} \mathrm{O}_{4}$ prepared in this manuscript has the largest adsorption capacity for $\mathrm{Pb}$ (II), reaching to $215.05 \mathrm{mg} / \mathrm{g}$, indicating that $6 \mathrm{O}-\mathrm{MWCNTs} @ \mathrm{Fe}_{3} \mathrm{O}_{4}$ has the best selective adsorption performance for $\mathrm{Pb}(\mathrm{II})$.

\section{Conclusions}

6O-MWCNTs magnetically modified by a solvothermal method, not only inherit their own advantages, such as a large specific surface area and abundant pore structure, but also exhibit a new magnetic properties and further improved adsorption capacity, which is conducive to the magnetic separation and recovery of heavy metals. The XRD, FTIR and SEM results indicate that carboxyl functional groups (-COOH) and magnetic groups $(\mathrm{Fe}-\mathrm{O})$ are effectively introduced on the surface of the obtained 6O-MWCNTs@ $\mathrm{Fe}_{3} \mathrm{O}_{4} \cdot \mathrm{Fe}_{3} \mathrm{O}_{4}$ particles are evenly distributed on the surface of the 6O-MWCNTs structure. Tubular 6O-MWCNTs appear like a needle thread connecting magnetic particles in series, forming a structure similar to a fishing net. The adsorption experiment shows that 6O-MWCNTs@ $\mathrm{Fe}_{3} \mathrm{O}_{4}$ have good selective adsorption performance for $\mathrm{Pb}(\mathrm{II})$, with a maximum adsorption capacity of $215.05 \mathrm{mg} / \mathrm{g}$, which is much higher than the existing adsorption capacity of the same type of adsorbents. The 6O-MWCNTs@ $\mathrm{Fe}_{3} \mathrm{O}_{4}$ after adsorbing metal ions can be separated quickly from solution under the action of an external magnetic field. FTIR and XPS results show that under the action of both coordination and electrostatic attraction, the $\mathrm{C}=\mathrm{O}$ bond in the $-\mathrm{COOH}$ group is induced to open by the metal ions and transforms into an ionic bond, and the metal ions are stably adsorbed on the surface of $6 \mathrm{O}-\mathrm{MWCNTs} @ \mathrm{Fe}_{3} \mathrm{O}_{4} \cdot \mathrm{Pb}$ (II) has a stronger attraction than $\mathrm{Cu}(\mathrm{II})$ and $\mathrm{Pd}(\mathrm{II})$ to the lone pair of electrons in oxygen atoms to form complexes, due to the covalent index of $\mathrm{Pb}$ (6.41) is more larger than that of $\mathrm{Cu}$ (2.98) and $\mathrm{Cd}$ (2.71). These data provide a new type of recyclable adsorbent for the efficient treatment of heavy metal ions in wastewater and enrich relevant theoretical knowledge.

Received: 21 May 2021; Accepted: 5 August 2021

Published online: 19 August 2021

\section{References}

1. Wang, Z. et al. Formation mechanism of Zinc-doped fayalite $\left(\mathrm{Fe}_{2-\mathrm{x}} \mathrm{Zn}_{\mathrm{x}} \mathrm{SiO}_{4}\right)$ slag during copper smelting. J. Hazard. Mater. 20, 488-498 (2019).

2. Zhao, Z. W. et al. Arsenic vitrification by copper slag based glass: Mechanism and stability studies. J. Non-Cryst. Solids 466-467, 21-28 (2017).

3. Biswas, A. K. \& Davenport, W. G. Extractive metallurgy of copper-third edition. Miner. Resour. Eng. 04, 215-216 (2012).

4. Tang, J.-Q., Xi, J.-B., Yu, J.-X., Chi, R.-A. \& Chen, J.-D. Novel combined method of biosorption and chemical precipitation for recovery of $\mathrm{Pb}^{2+}$ from wastewater. Environ. Sci. Pollut. Res. 25, 28705-28712 (2018).

5. Villaseor-Basulto, D. L., Astudillo-Sánchez, P. D., Del Real-Olvera, J. \& Bandala, E. R. Wastewater treatment using Moringa oleifera Lam seeds: A review. J. Water Process Eng. 23, 151-164 (2018).

6. Renu, M. \& Agarwal, K. Singh, Methodologies for removal of heavy metal ions from wastewater: An overview. Interdiscip. Environ. Rev. 18, 124-142 (2017).

7. Efome, J. E., Rana, D., Matsuura, T. \& Lan, C. Q. Effects of operating parameters and coexisting ions on the efficiency of heavy metal ions removal by nano-fibrous metal-organic framework membrane filtration process. Sci. Total Environ. 674, 355-362 (2019).

8. Peng, H. \& Guo, J. Removal of chromium from wastewater by membrane filtration, chemical precipitation, ion exchange, adsorption electrocoagulation, electrochemical reduction, electrodialysis, electrodeionization, photocatalysis and nanotechnology: a review. Environ. Chem. Lett. 2, 1-14 (2020).

9. Ates, N. \& Uzal, N. Removal of heavy metals from aluminum anodic oxidation wastewaters by membrane filtration. Environ. Sci. Pollut. Res. 25, 22259-22272 (2018).

10. Zhang, C. et al. Three-dimensional electrochemical process for wastewater treatment: A general review. Chem. Eng. J. Lausanne228, 455-467 (2013)

11. Wang, L. K., Shammas, N. K. \& Hung, Y. T. Advanced physicochemical treatment technologies. Handb. Environ. Eng. 4, 67-68 (2007).

12. Li, C. C., Lin, J. L., Huang, S. J., Lee, J. T. \& Chen, C. H. A new and acid-exclusive method for dispersing carbon multi-walled nanotubes in aqueous suspensions. Colloids Surf. A 297, 275-281 (2007).

13. Wang, S. G. et al. Removal of lead(II) from aqueous solution by adsorption onto manganese oxide-coated carbon nanotubes. Sep. Purif. Technol. 58, 17-23 (2007).

14. Li, Y. et al. Removal of copper from aqueous solution by carbon nanotube/calcium alginate composites. J. Hazard. Mater. 177, 876-880 (2010).

15. Li, Y. H. et al. Adsorption of fluoride from water by aligned carbon nanotubes. Mater. Res. Bull. 38, 469-476 (2003).

16. Peng, X., Luan, Z., Di, Z., Zhang, Z. \& Zhu, C. Carbon nanotubes-iron oxides magnetic composites as adsorbent for removal of $\mathrm{Pb}(\mathrm{II})$ and $\mathrm{Cu}(\mathrm{II})$ from water. Carbon $43,880-883$ (2005).

17. Pillay, K., Cukrowska, E. M. \& Coville, N. J. Multi-walled carbon nanotubes as adsorbents for the removal of parts per billion levels of hexavalent chromium from aqueous solution. J. Hazard. Mater. 166, 1067-1075 (2009).

18. Gupta, V. K., Agarwal, S. \& Saleh, T. A. Chromium removal by combining the magnetic properties of iron oxide with adsorption properties of carbon nanotubes. Water Res. 45, 2207-2212 (2011).

19. Huang, Z. N. Adsorption of Cr(VI) in wastewater using magnetic multi-wall carbon nanotubes. Water Sci. Eng. 3, 226-232 (2015).

20. Mittal, A. et al. Fabrication of MWCNTs/ThO 2 nanocomposite and its adsorption behavior for the removal of $\mathrm{Pb}(\mathrm{II})$ metal from aqueous medium. Desalin. Water Treat. Sci. Eng. 57, 21863-21869 (2016).

21. Lung, I. et al. Evaluation of CNT-COOH/MnO $/ \mathrm{Fe}_{3} \mathrm{O}_{4}$ nanocomposite for ibuprofen and paracetamol removal from aqueous solutions. J. Hazard. Mater. 403, 1-15 (2021).

22. Madrid, S. I. U., Pal, U. \& Jesus, S. D. Controlling size and magnetic properties of $\mathrm{Fe}_{3} \mathrm{O}_{4}$ clusters in solvothermal process. $A d v$. Nano Res. 2, 187-198 (2014).

23. Sodan, N. E., Hol, A., Caylak, O. \& Elci, L. Use of $\mathrm{Fe}_{3} \mathrm{O}_{4}$ magnetic nanoparticles coated with polythiophene for simultaneous preconcentration of $\mathrm{Cu}$ (II), $\mathrm{Co}$ (II), $\mathrm{Cd}$ (II), $\mathrm{Ni}$ (II) and $\mathrm{Zn}(\mathrm{II})$ ions prior to their determination by MIS-FAAS. Acta Chim. Slov. 67, 375-385 (2020). 
24. Nehru, S., Sakthinathan, S., Tamizhdurai, P., Chiu, T. W. \& Shanthi, K. Reduced graphene oxide/multiwalled carbon nanotube composite decorated with $\mathrm{Fe}_{3} \mathrm{O}_{4}$ magnetic nanoparticles for electrochemical determination of hydrazine in environmental water. J. Nanosci. Nanotechnol. 20, 3148-3156 (2020).

25. Wang, Z., Liang, Y., Peng, N. \& Peng, B. The non-isothermal kinetics of zinc ferrite reduction with carbon monoxide. J. Therm. Anal. Calorim. 136, 2157-2164 (2019).

26. Wang, Z. et al. Investigation on the mechanism of the immobilization of $\mathrm{CeO}_{2}$ by using cullet-based glass (CBG). Ann. Nucl. Energy 133, 209-215 (2019).

27. Kim, S. D., Ju, W. K., Ji, S. I., Kim, Y. H. \& Lee, Y. S. A comparative study on properties of multi-walled carbon nanotubes (MWCNTs) modified with acids and oxyfluorination. J. Fluorine Chem. 128, 60-64 (2007).

28. Dini, Z., Afsharpour, M. \& Heidar, K. T. UV-assisted functionalization of carbon nanotube for synthesis of efficient desulfurization catalysts $\left(\mathrm{NH}_{2} / \mathrm{COOH}\right)-\mathrm{MWNT} / \mathrm{MoO}_{3}$. Diam. Relat. Mater. 91, 237-246 (2019).

29. Libowitzky, E. Correlation of O-H stretching frequencies and O-H...O hydrogen bond lengths in minerals. Monatshefte für Chemie / Chemical Monthly 130, 1047-1059 (1999).

30. Vahur, S., Teearu, A., Peets, P., Joosu, L. \& Leito, I. ATR-FT-IR spectral collection of conservation materials in the extended region of $4000-80 \mathrm{~cm}^{-1}$. Anal. Bioanal. Chem. 408, 3373-3379 (2016).

31. Vila, R. Induction of Secondary Structure in a COOH-terminal Peptide of Histone H1 by Interaction with the DNA. J. Biol. Chem. 276, 30898-30903 (2001).

32. Hellwig, W. P. Infrared spectra and molar absorption coefficients of the 20 alpha amino acids in aqueous solutions in the spectral range from 1800 to $500 \mathrm{~cm}^{-1}$. Spectrochim. Acta Part A Mol. Biomol. Spectroscopy 64, 987-1001 (2006).

33. Zhu, Y., Zhao, W., Zhang, J., An, Z. \& He, J. Selective activation of $\mathrm{C}-\mathrm{OH}, \mathrm{C}-\mathrm{O}-\mathrm{C}$, or $\mathrm{C}=\mathrm{C}$ in furfuryl alcohol by engineered $\mathrm{Pt}$ sites supported on layered double oxides. ACS Catal. 10, 8032-8041 (2020).

34. $\mathrm{Fe}^{\mathrm{III}}$-hydroperoxo and peroxo complexes with aminopyridyl ligands and the resonance raman spectroscopic identification of the $\mathrm{Fe}-\mathrm{O}$ and $\mathrm{O}-\mathrm{O}$ stretching modes. Eur. J. Inorg. Chem. 2000, 1627-1633 (2000).

35. Liu, D. G. et al. Co-treatment of flotation waste, neutralization sludge, and arsenic-containing gypsum sludge from copper smelting: Solidification/stabilization of arsenic and heavy metals with minimal cement clinker. Environ. Sci. Pollut. Res. Int. 25, 7600-7607 (2018)

36. Wang, Y., Hase, W. L. \& Song, K. Direct dynamics study of N-protonated diglycine surface-induced dissociation. Influence of collision energy. J. Am. Soc. Mass Spectrom. 14, 1402-1412 (2003).

37. Puziy, A. M., Poddubnaya, O. I. \& Ziatdinov, A. M. On the chemical structure of phosphorus compounds in phosphoric acidactivated carbon. Appl. Surf. 252, 8036-8038 (2006).

38. Kanai, H., Yoshiki, M., Hayashi, M., Kuwae, R. \& Yamashita, Y. Grain-boundary-phase identification of a lead-based relaxor by X-ray photoelectron spectroscopy. J. Am. Ceram. Soc. 77, 2229-2231 (2010).

39. Milanova, M. Glass formation in the $\mathrm{CuO}-\mathrm{MoO}_{3}$ system. J. Non-Cryst. Solids 355, 379-385 (2009).

40. Ren, Y., Li, N., Feng, J., Luan, T. \& Zhang, M. Adsorption of $\mathrm{Pb}(\mathrm{II})$ and $\mathrm{Cu}(\mathrm{II})$ from aqueous solution on magnetic porous ferrospinel $\mathrm{MnFe}_{2} \mathrm{O}_{4}$. J Colloid Interf Sci 367, 415-421 (2011).

41. Chen, J., Chen, W. \& Zhu, D. Adsorption of nonionic aromatic compounds to single-walled carbon nanotubes: Effects of aqueous solution chemistry. Environ. Sci. Technol. 42, 7225-7230 (2008).

42. Jin, Li. Mechanisms of lead adsorption on chitosan/PVA hydrogel beads. Langmuir 18, 9765-9770 (2002).

43. Rastogi, N., Mitra, K., Kumar, D. \& Raja, R. Metal ions as cofactors for aggregation of therapeutic peptide salmon calcitonin. Inorg. Chem. 51, $5642(2012)$

44. Yang, J., Wu, J. X., Lü, Q. \& Lin, T. T. facile preparation of lignosulfonate-graphene oxide-polyaniline ternary nanocomposite as an effective adsorbent for $\mathrm{Pb}(\mathrm{II})$ ions. Acs Sustain. Chem. Eng. 2, 1203-1211 (2014).

45. Turgut, G. \& Sönmez, E. A study of Pb-doping effect on structural, optical, and morphological properties of $\mathrm{ZnO}$ thin films deposited by sol-gel spin coating. Metall. Mater. Trans. A. 45, 3675-3685 (2014).

46. Ramesh, M., Rao, G., Samatha, K. \& Rao, B. P. Cation distribution of Ni-Cu substituted Li-ferrites. Ceram. Int. 41, 1765-1770 (2015).

47. Iqbal, M., Ibrar, A., Ali, A., Rehman, F. \& Thebo, K. H. Facile synthesis of Zn Doped CdS nanowires with efficient photocatalytic performance. Environ. Technol. ISSN 1, 1-10 (2020).

48. Brady, J. M. \& Tobin, J. M. Binding of hard and soft metal ions to rhizopus arrhizus biomass. Enzyme Microb. Technol. 17, 791-796 (1995).

49. Nieboer, E. \& Richardson, D. The replacement of the nondescript term "heavy metals" by a biologically and chemically significant classification of metal ions. Environ. Pollut. B. 1, 3-26 (1980).

50. Chen, C. \& Wang, J. Influence of metal ionic characteristics on their biosorption capacity by Saccharomyces cerevisiae. Appl. Microbiol. Biotechnol. 74, 911-917 (2007).

51. $\mathrm{Li}$, S. et al. Recyclable CNTs/ $/ \mathrm{Fe}_{3} \mathrm{O}_{4}$ magnetic nanocomposites as adsorbents to remove bisphenol A from water and their regeneration. Chem. Eng. J. 260, 231-239 (2015).

52. Nassereldeen, A. K. et al. Kinetic adsorption of application of carbon nanotubes for $\mathrm{Pb}(\mathrm{II})$ removal from aqueous solution. J. Environ. Sci. 2, 539-544 (2009).

53. Zhang, $\mathrm{H}$. et al. Uptake of $\mathrm{Pb}(\mathrm{II})$ and $\mathrm{Cd}(\mathrm{II})$ on chitosan microsphere surface successively grafted by methyl acrylate and diethylenetriamine. ACS Appl. Mater. Interfaces 2, 2 (2017).

54. $\mathrm{Zhu}, \mathrm{Y} ., \mathrm{Hu}, \mathrm{J}$. \& Wang, J. Competitive adsorption of $\mathrm{Pb}(\mathrm{II}), \mathrm{Cu}(\mathrm{II})$ and $\mathrm{Zn}(\mathrm{II})$ onto xanthate-modified magnetic chitosan. J. Hazard. Mater. 221-222, 155-161 (2012).

55. Shen, Y. F., Tang, J., Nie, Z. H., Wang, Y. D. \& Zuo, L. Preparation and application of magnetic $\mathrm{Fe}_{3} \mathrm{O}_{4}$ nanoparticles for wastewater purification. Sep. Purif. Technol. 68, 312-319 (2009)

56. Wang, L. et al. Anionic polypeptide poly( $\gamma$-glutamic acid)-functionalized magnetic $\mathrm{Fe}_{3} \mathrm{O}_{4}$-GO-(O-MWCNTs) hybrid nanocomposite for high-efficiency removal of $\mathrm{Cd}(\mathrm{II}), \mathrm{Cu}(\mathrm{II})$ and $\mathrm{Ni}(\mathrm{II})$ heavy metal ions. Chem. Eng. J. 346, 38-49 (2018).

57. Mubarak, N. M., Sahu, J. N., Abdullah, E. C., Jayakumar, N. S. \& Ganesan, P. Microwave assisted multiwall carbon nanotubes enhancing Cd(II) adsorption capacity in aqueous media. J. Ind. Eng. Chem. 24, 24-33 (2015).

\section{Acknowledgements}

The authors gratefully acknowledge financial support from the National Natural Science Foundation of China (52064038). The Guangdong Provincial Key Laboratory of R\&D for Resource Utilization and Deep Treatment of Hazardous Waste Liquid (2018B030323016).

\section{Author contributions}

Z.W.: Conceived and designed the experiments; contributed on the writing of the manuscript. W.X.: contributed reagents/materials/analysis tools. F.J.: analyzed the data. Z.Z.: contributed on the writing of the manuscript. K.Z.: performed the experiments. H.L.: reviewed and revised the manuscript. 


\section{Competing interests}

The authors declare no competing interests.

\section{Additional information}

Supplementary Information The online version contains supplementary material available at https://doi.org/ 10.1038/s41598-021-96465-7.

Correspondence and requests for materials should be addressed to Z.W. or Z.Z.

Reprints and permissions information is available at www.nature.com/reprints.

Publisher's note Springer Nature remains neutral with regard to jurisdictional claims in published maps and institutional affiliations.

(c) (1) Open Access This article is licensed under a Creative Commons Attribution 4.0 International License, which permits use, sharing, adaptation, distribution and reproduction in any medium or format, as long as you give appropriate credit to the original author(s) and the source, provide a link to the Creative Commons licence, and indicate if changes were made. The images or other third party material in this article are included in the article's Creative Commons licence, unless indicated otherwise in a credit line to the material. If material is not included in the article's Creative Commons licence and your intended use is not permitted by statutory regulation or exceeds the permitted use, you will need to obtain permission directly from the copyright holder. To view a copy of this licence, visit http://creativecommons.org/licenses/by/4.0/.

(C) The Author(s) 2021 